\title{
EFFECT OF TWO DIFFERENT METHODS REDUCING BODY MASS (RAPID AND MEDIUM RAPID) ON PROFESSIONAL WRESTLERS' CHANGES IN BODY COMPOSITION AND FORCE
}

\author{
Birutė Matulevičiūtè ${ }^{1}$, Renata Žumbakytė-Šermukšnienè $\dot{1}^{1,2}$, \\ Pranas Mockus ${ }^{2}$, Agnẻ Bieliūnaite் ${ }^{1}$ \\ Lithuanian University of Health Sciences, Medical Academy ${ }^{l}$, Kaunas, Lithuania \\ Lithuanian Sports University', Kaunas, Lithuania
}

\begin{abstract}
Research background and hypothesis. Wrestlers often want to reduce body mass during a short period of time. According to literature, it is important not to change body composition when reducing body mass. It has been intended to examine muscle force changes when reducing body mass rapidly and averagely rapidly.

Research aim was to estimate the effect of methods reducing body mass (rapid, averagely rapid) on wrestlers' changes in body mass components and force.

Research methods. Groups of research participants: one - wrestlers who did not reduce body mass $(n=47)$, two - wrestlers who reduced body mass rapidly $(\mathrm{n}=16)$, three - wrestlers who reduced body mass averagely rapidly ( $\mathrm{n}=9$ ). Muscle force (dynamometer MMT) and mass components (bio-impedance method Tanita 300) were estimated before and after reducing body mass.

Research results. Before reducing body mass (rapidly, averagely rapidly) wrestlers' body mass was greater $(\mathrm{p}<0.05)$ than after reducing it. Wrestlers lost $4.5 \%$ of body mass when reducing it rapidly (24-72 hours), when averagely rapidly ( 72 hours -2 weeks) $-4.03 \%$. After reducing body mass fat free body mass decreased tendentiously. Using rapid method, wrestlers' force of both legs diminished $(\mathrm{p}<0.05)$, when using averagely rapid method, force of left leg diminished $(p<0.05)$. Force of arms decreased $(p<0.05)$ after reducing body mass by both methods.

Discussion and conclusions. Subjects used aggressive method of reducing body mass. They need appropriate training about athlete nutrition, optimal reduced body mass. Tendentious decrease in free body mass shows decrease in muscle force.

Force in arms and legs significantly decreased for wrestlers using rapid and averagely rapid methods for reducing body mass.
\end{abstract}

Keywords: reducing body mass, mass components, change in force, judo.

\section{INTRODUCTION}

$\mathrm{F}$ ine physical qualification and good functional fitness are important in every type of sport. Wrestlers start reducing body mass before competitions in order to get into appropriate weight category disregarding techniques of reducing body mass and their influence on health. It is very important to avoid dehydration when reducing body mass. K. Vodopalas and others (2008) state that the reason why physical efficiency of muscles decreases is loss of liquids - dehydration. Due to dehydration the state of heart and blood vessels declines. Frequently, when reducing body mass and not drinking enough liquids (which is important during intense training), body mass falls due to liquids loss and decrease in muscles force. Dehydration of about 3-4 per cent of body mass 
definitely reduces muscle endurance during high intensity exercise because muscle strength usually becomes smaller (Lambert, Jones, 2010).

R. Kordi and co-authors (2012) state that during rapid method of reducing body mass athletes lose liquids that can cause loss of glycogen. More than a half of wrestlers who participated in the research started reducing body mass for 3 days or less, the average was $4.0 \pm 2.1$ days. Gradually reducing body mass (several weeks or months) it decreases due to fat loss (Kordi et al., 2012).

According to American Dietetic Association and co-authors (2009) proper food and liquids should be used before, during and after physical activity to help keeping blood glucose concentration levels during physical activity (American Dietetic Association, 2009). If optimal method of reducing body mass is chosen, the energy should be used from the fatty tissue. Scientists states that choosing the proper diet is more important than reducing body mass rapidly in order to lose less force until competition (Lambert, Jones, 2010). During dehydration, when $1-2 \%$ of body mass decrease due to loss of liquids, the body temperature increases. After $3-5 \%$ decrease of body mass, the body temperature increases more, physical aerobic and anaerobic efficiency and strength decrease, after $6 \%$ decrease of body mass muscle spasms and cramps start. After $10 \%$ or more decrease of body mass, the body temperature increases more and can harmfully affect heart and blood vessels, the risk of heat stroke increases and can cause death (Baranauskas, 2010).

Usually wrestlers reduce body mass rapidly (during 24-72 hours) and averagely rapidly (from 72 hours until 2 weeks) and expect good results during competitions without losing force. Consequently, the objective of this paper was to estimate the influence of rapid and averagely rapid methods of reducing body mass on wrestlers' force.
The aim of research was to estimate the effect of two different methods (rapid and averagely rapid) on professional wrestlers' changes in body composition and force.

\section{RESEARCH METHODS}

There were three groups distinguished: the first group (control group) - wrestlers who did not reduce body mass $n=47$, the second group wrestlers who reduced body mass rapidly (from 24 to 72 hours) $n=16$, the third group - wrestlers who reduced body mass averagely rapidly (from 72 hours to 2 weeks) $n=9$.

The testing of wrestlers were accomplished before training and 24 hours after the last training without consuming liquids 4 hours before testing. The first testing was accomplished during the cycle of training when wrestlers did not reduce body mass. All three groups were tested. The second testing was carried out on the last day before competition where all three groups were tested as well.

Body mass components were estimated by bioelectrical impedance analysis method using body composition analyzer TBF-300'(TANITA). Subject stood on special scales with electrodes. During the analysis low-level $(50 \mathrm{~Hz})$ constant electric current was passed through subject's body and special device measured impedance. The accuracy and reliability of the method is similar to skinfold analysis (Ostojic, 2006; Žumbakyte, 2006). The indicators used were: body mass index (BMI, $\left.\mathrm{kg} / \mathrm{m}^{2}\right)$, body mass $(\mathrm{kg})$, body fat mass (\%), fat free body mass $(\mathrm{kg})$, body water mass $(\mathrm{kg})$.

Muscle force testing was accomplished using Nicholas Manual Muscle Tester. Dynamometer measured force with $0.1 \mathrm{~kg}$ accuracy in $0.9-$ $199.9 \mathrm{~kg}$ range (Sisto, Dyson-Hudson, 2007). The maximum force of hip flexion and shoulder

\begin{tabular}{|c|c|c|c|c|c|}
\hline Group & Sample & Age, years & Height, cm & $\begin{array}{c}\text { Body mass, } \\
\text { kg }\end{array}$ & $\begin{array}{c}\text { Body mass index, } \\
\mathrm{kg} / \mathrm{m}^{2}\end{array}$ \\
\hline $\begin{array}{l}\text { Wrestlers who reduced } \\
\text { body mass rapidly }\end{array}$ & 16 & $20.25 \pm 1.22$ & $179.38 \pm 1.27$ & $80.53 \pm 2.74$ & $24.79 \pm 0.63$ \\
\hline $\begin{array}{l}\text { Wrestlers who reduced } \\
\text { body mass averagely } \\
\text { rapidly }\end{array}$ & 9 & $21 \pm 0.84$ & $180.78 \pm 3.37$ & $76.78 \pm 2.95$ & $23.2 \pm 0.54$ \\
\hline $\begin{array}{l}\text { Wrestlers who did not } \\
\text { reduce body mass }\end{array}$ & 47 & $20.79 \pm 0.6$ & $180.68 \pm 1.02$ & $79.89 \pm 2.41$ & $24.37 \pm 0.6$ \\
\hline
\end{tabular}


Figure 1. The course of investigations

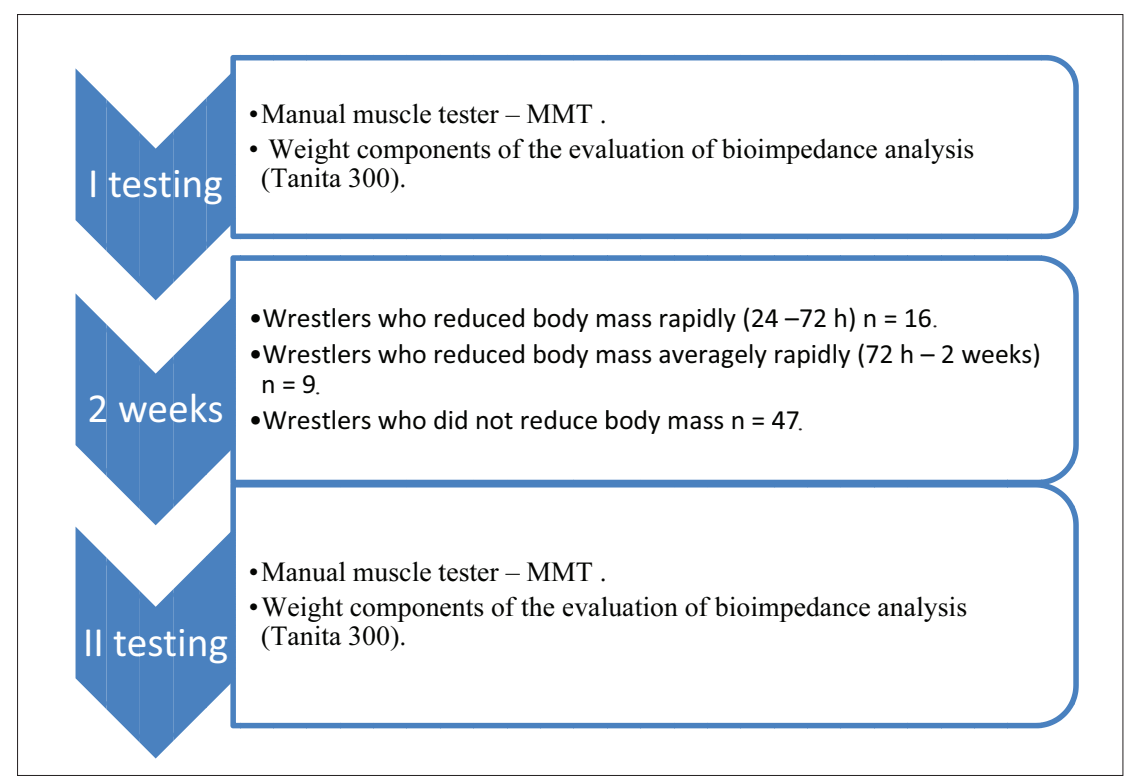

abduction was measured. The test was carried out so that not more than two joints would be used to perform a movement. The primary position of the subject was sitting on a couch with shoulder abduction of 90 degrees, straight back and legs not reaching the ground. The tester countervailed in the distal forearm zone.

When testing hip flexion, subject also sat on a couch, with a straight back and legs not reaching the ground, the leg bent to 90 degrees. The tester countervailed by putting dynamometer in the distal zone of hip. If athlete used compensatory muscles during the testing movement, the testing was stopped and repeated from the beginning. There were three tests with breaks among them. The average of those three results was calculated (Sisto, Dyson-Hudson, 2007).

Mathematical statistics. SPSS software package was used for data analysis. For comparison of independent samples (for groups which did not reduce body mass and reduced body mass using rapid and averagely rapid methods), non-parametric Mann-Whitney-Wilcoxon test was used. For comparison of dependable sample (for the first and second test results), non-parametric Wilcoxon test was applied. Differences were considered statistically significant when $\mathrm{p}<0.05$ was set. The results are represented as arithmetic mean \pm the standard error of the mean (SEM).

\section{RESEARCH RESULTS}

Before reducing body mass by rapid and averagely rapid methods, wrestlers' body mass was statistically significantly greater $(p<0.05)$ than after reducing body mass. The body mass of wrestlers who did not reduce body mass did not change (Figure 2).

Wrestlers who reduced body mass rapidly had higher percentage of fat mass after reducing body mass but it was not statistically significant ( $p>0.05$ ) ( before $-9.44 \%$, after $-10.48 \%$ ). Before reducing body mass the percentage of body fat mass for averagely rapid method group and for those who did not reduce body mass did not change.

Changes of fat free body mass are represented in Figure 3. Fat free body mass changed insignificantly after reducing body mass rapidly and averagely rapidly $(p>0.05)$. For wrestlers who did not reduce body mass, fat free body mass did not change.

The force of the left and right legs before reducing body mass in the group of wrestlers who reduced body mass rapidly was statistically signifantly $(\mathrm{p}<0.05)$ greater than after reducing body mass. For wrestlers who reduced body mass using averagely rapid method the force of the left leg was statistically significantly lower $(p<0.05)$. The force of the right leg had a tendency to get lower $(p>0.05)$ after reducing body mass. The force remained the same for those who did not reduce body mass $(p>0.05)$. The force of both legs was statistically significantly greater of for wrestlers who reduced body mass rapidly than for those who did not reduce body mass $(\mathrm{p}<0.05)$. After reducing body mass the force was not statistically significantly different. Change in force is represented in the Figure 4. 


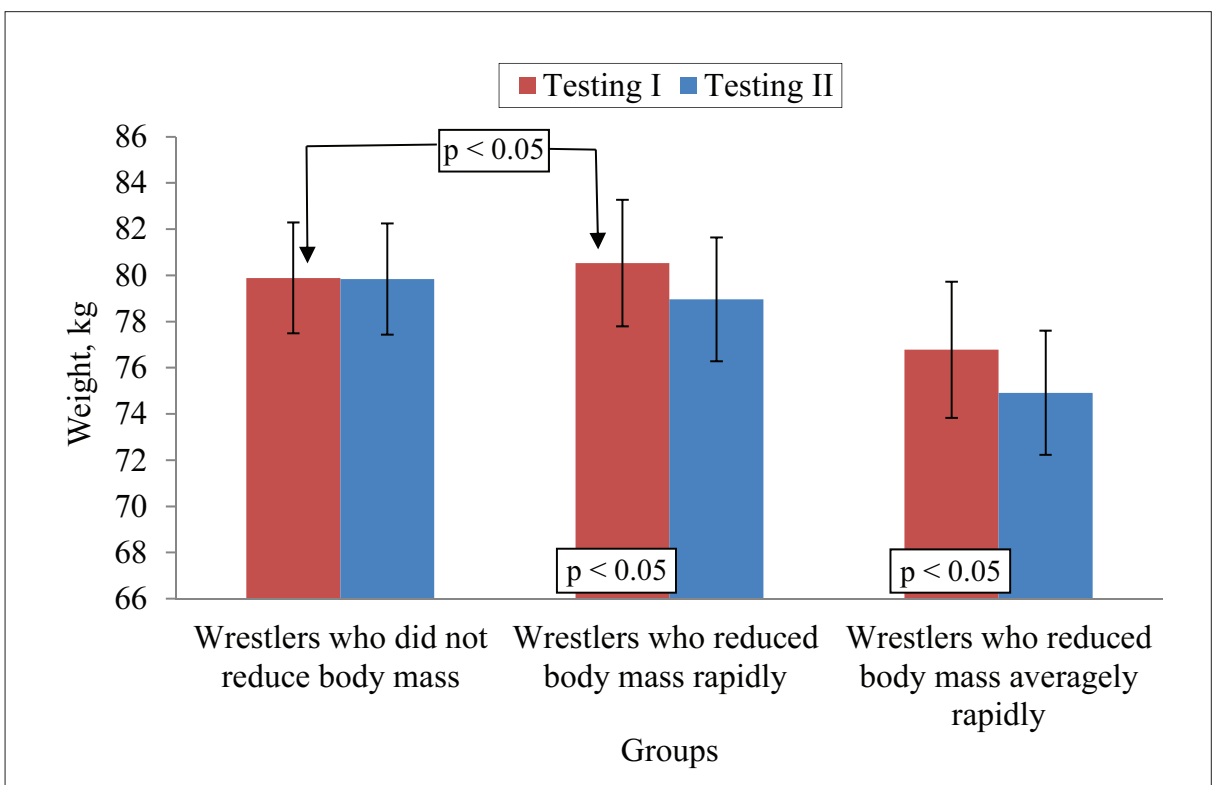

Figure 2. Wrestlers' body mass changes

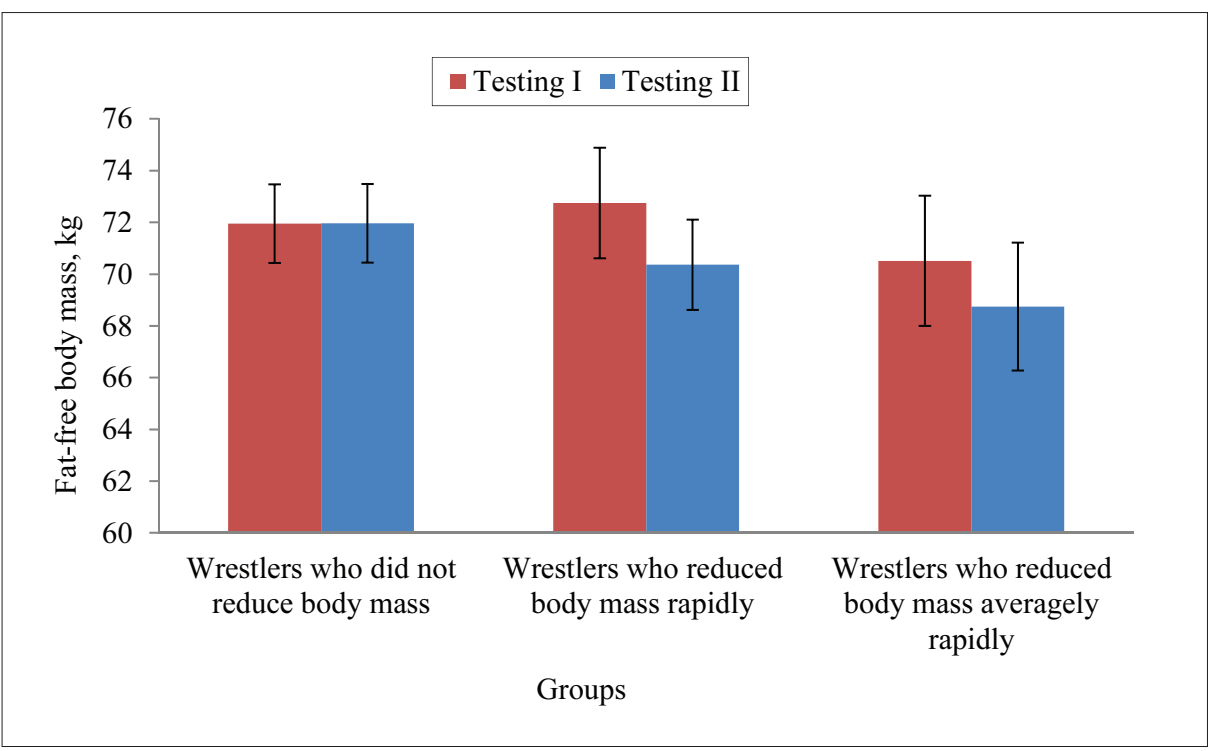

Figure 3. Wrestlers' fat-free body mass changes

Figure 4. Wrestlers' left leg changes

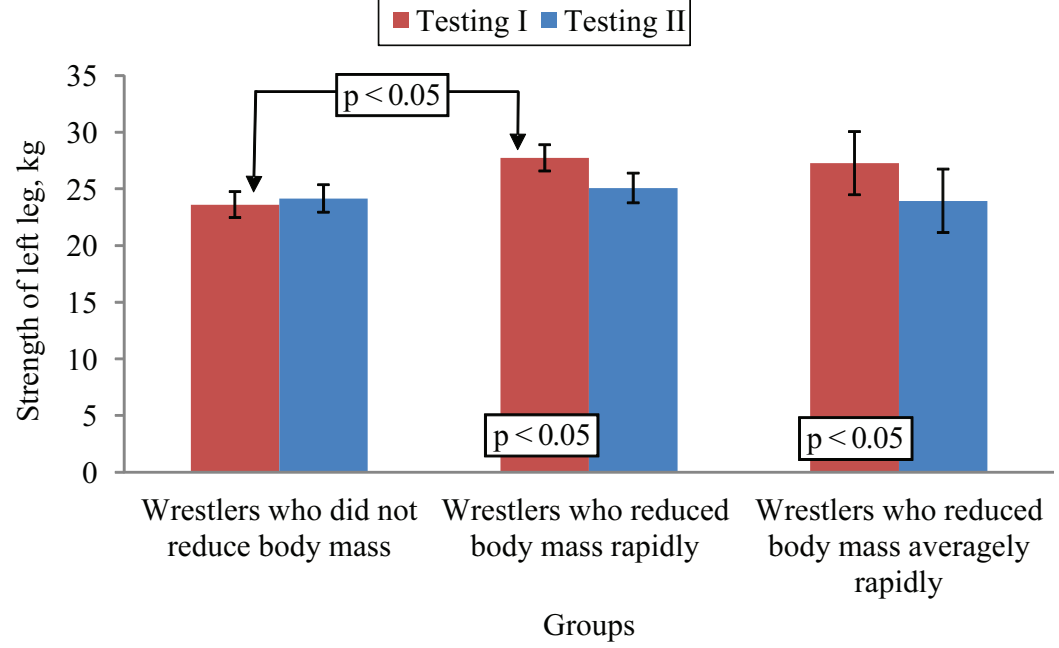


Figure 5. Wrestlers' left arm force changes

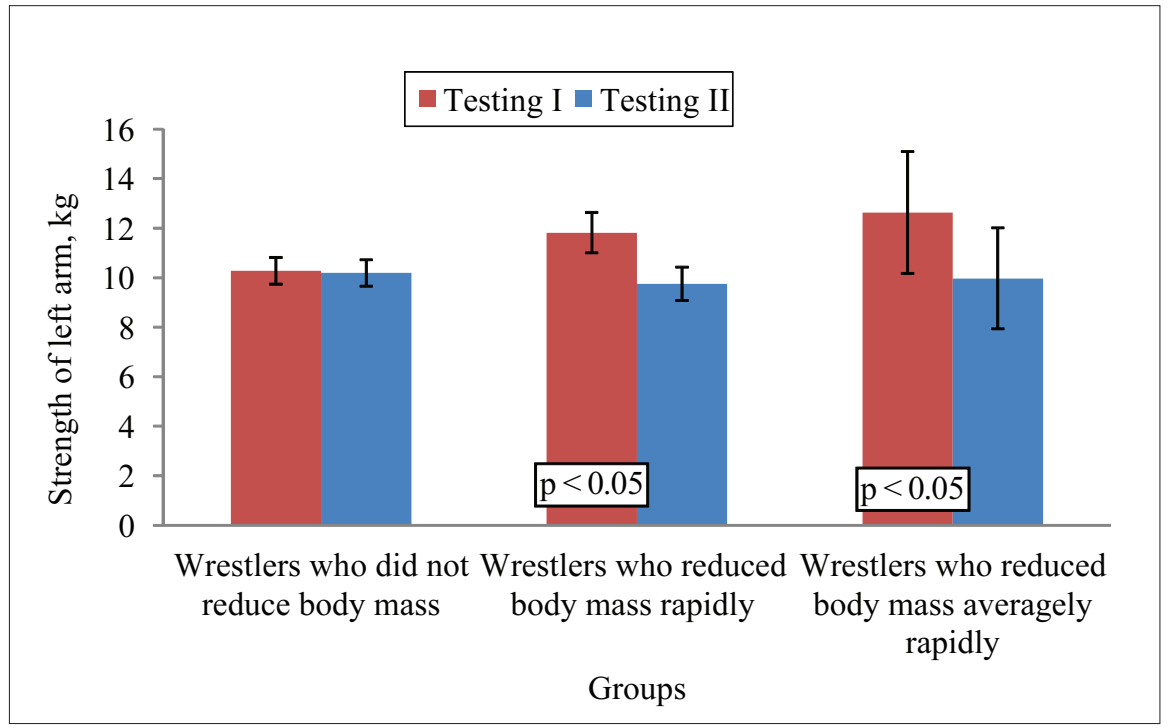

Force in the right and left arms for wrestlers who did not reduced body mass did not change $(p>0.05)$. Force in both legs became statistically significantly $(\mathrm{p}<0.05)$ lower for those wrestlers who reduced body mass rapidly. After reducing body mass for wrestlers who reduced body mass averagely rapidly force in both hands became statistically significantly lower $(p<0.05)$. Change in hand force can be observed in the Figure 5.

\section{DISCUSSION}

In the pre-competition period wrestlers usually start reducing body mass in order to get into appropriate weight category. Aiming at winning is not always related to athlete's health and wellbeing. Athletes not always can find the best method for reducing body mass independently. In their research R. B. Kiningham and D. V. Gorenflo (2001) show that $2 \%$ of wrestlers out of 2532 used diuretics, vomiting, diet pills and laxative medications. We also noticed a trend that athletes used to overeat after reducing body mass.

Judo wrestlers often lose a lot of mass which is connected with deep dehydration (Matias et al., 2010). Stopping eating and dehydration are some of the most popular methods of reducing body mass among wrestlers (Kiningham, Gorenflo, 2001).

Often wrestlers use rapid body mass reduction method. According to I. Garthe, fat free body mass increased more during slow method than rapid method, but fat mass (\%) and body water mass remained the same (Garthe et al., 2011). It shows that athletes reduced body mass getting less energy needed from nutrients. Our research shows that in averagely rapid method, fat free body mass had the tendency to get lower and body fat mass did not change. During the rapid method fat free body mass had the tendency to get lower, but body fat mass had the tendency to grow. It is possible that it was caused by inappropriate nutrition before reducing body mass.

A lot of athletes decrease their body mass by $5-10 \%$ in a week in the pre-competition period. Aggressive methods of reducing body mass are popular among athletes who participate in high level competitions. G. Artioli and co-authors (2010) state that an athlete should not lose more than $1.5 \%$ body mass. M. Baranauskas (2010) states that $37 \%$ of duelists lose from $4.6 \%$ to $6 \%$ body mass during 24-72 hours and do it insecurely. Therefore all the athletes who want to reduce their body mass and to keep their health and physical efficiency rates have to set their outlines (plans) for reducing body mass, to consult nutrition specialists and to reduce body mass slowly, i. e. in two weeks or more.

During our research wrestlers lost $4.5 \%$ body mass reducing body mass by a rapid method (24-72 hours), and averagely rapid method (from 72 hours to 2 weeks) lost $4.03 \%$. It shows that wrestlers who participated in our research used aggressive rapid method. Age is also very important when an athlete has started to control it (Artioli et al., 2010 b).

Following three deaths in 1997, the National Collegiate Athletic Association implemented a program which prevents wrestlers from wrestling below a minimum weight of $5 \%$ body fat (Loenneke et al., 2011). 
Reducing body mass by $5 \%$ using rapid method (3 days) did not change vertical jump with strain significantly for experienced athletes whereas using average rapid method ( 3 weeks) jump even increased by $6-8 \%$ (Fogelholm et al., 1993). J. Koral and F. Dosseville (2009) state that reducing $2-6 \%$ body mass one day before competition caused several disorders but judo movements during $5 \mathrm{~s}$ were not affected (Koral, Dosseville, 2009). According to I. Garthe and co-authors, when reducing body mass slowly, fat free body mass and upper limbs muscle force increase more than when reducing body mass rapidly when body mass in both groups decreases without changes in body composition (Garthe et al., 2011). In our research force in arms and legs decreased statistically significantly for wrestlers using rapid and averagely rapid methods reducing body mass. Therefore both rapid and averagely rapid methods reducing body mass caused changes in body composition and muscle force. It can be considered that wrong nutrition could have influence for such result which is a matter of great concern. Appropriate training about athlete nutrition is essential for wrestlers who reduce body mass. In our case tendentious fat free body mass shows diminishing muscle force. Therefore coaches and operating personnel have to seek that wrestlers would reduce body mass without changes in body composition.

\section{CONCLUSIONS AND PERSPECTIVES}

1. Force in arms and legs decrease for both wrestlers using rapid and averagely rapid methods reducing body mass.

2. Tendentious decrease in fat free body mass indicates diminishing force in arms and legs.

\section{REFERENCES}

American Dietetic Association, Dietitians of Canada, American College of Sports Medicine. Rodriguez, N. R., Di Marco, N. M., Langley, S. (2009). American College of Sports Medicine position stand. Nutrition and athletic performance. Medicine and Science in Sport and Exercise, 41 (3), 709-731.

Artioli, G. G, Franchini, E., Nicastro, H. et al. (2010). The need of a weight management control program in judo: A proposal based on the successful case of wrestling. Journal of the International Society of Sports Nutrition, 7, 15.

Artioli, G. G., Gualano, B., Franchini, E. et al. (2010). Prevalence, magnitude, and methods of rapid weight loss among judo competitors. Medicine and Science in Sport and Exercise, 42 (3), 436-442.

Baranauskas, M. (2010). Drastiško lieknejjimo sporte nauda ir žala - diskusijų objektas. Treneris, 3 (4), 7-20.

Fogelholm, G. M., Koskinen, R., Laakso, J, Rankinen, T., Ruokonen, I. (1993). Gradual and rapid weight loss: Effects on nutrition and performance in male athletes. Medicine and Science in Sport and Exercise, 25 (3), 371-377.

Garthe, I., Raastad, T., Sundgot-Borgen, J. (2011). Long-term effect of weight loss on body composition and performance in elite athletes. International Journal of Sport Nutrition and Exercise Metabolism, 21 (5), 426-435.

Kiningham, R. B., Gorenflo, D. W. (2001). Weight loss methods of high school wrestlers. Medicine and Science in Sport and Exercise, 33 (5), 810-813.

Koral J, Dosseville F. (2009). Combination of gradual and rapid weight loss: Effects on physical performance and psychological state of elite judo athletes. Journal of Sports Sciences, 27(2), 115-20.
Kordi, R., Nourian, R., Rostami, M., Wallace, W. A. (2012). Percentage of body fat and weight gain in participants in the Tehran high school wrestling championship. Asian Journal of Sports Medicine, 3 (2), 119-125.

Lambert, C., Jones, B. (2010). Alternatives to rapid weight loss in US wrestling. International Journal of Sports Medicine, 31 (8), 533-528.

Loenneke, J. P., Wilson, J. M., Barnes, J. T., Pujol, T. J. (2011). Validity of the current NCAA minimum weight protocol: A brief review. Annals of Nutrition \& Metabolism, 58 (3), 245-249.

Matias, C. N., Santos, D. A., Monteiro, C. P. et al. (2010). Magnesium and strength in elite judo athletes according to intracellular water changes. Magnesium Research: Official Organ of International Society for the Development of Research on Magnesium, 23 (3), 138-141.

Ostojic, S. M. (2006). Estimation of body fat in athletes: Skinfolds vs. bioelectrical impedance. Journal of Sports Medicine and Physical Fitness, 46 (3), 442-446.

Sisto, S. A., Dyson-Hudson, T. (2007). Dynamometry testing in spinal cord injury. Journal of Rehabilitation Research \& Development, 44 (1), 123-136.

Vadopalas, K., Skurvydas, A., Brazaitis, M. et al. (2008). Hipertermijos ir dehidratacijos poveikis aktyviai sportuojančių vyrų griaučių raumenų nuovargiui atliekant maksimalaus intensyvumo izometrinius krūvius. Ugdymas. Kūno Kultūra. Sportas, 2 (69), 101-108.

Žumbakytė, R. (2006). Krepšininku ir futbolininku funkcinès būklès ypatybès naudojant integraliojo vertinimo modeli: daktaro disertacija. Kauno medicinos universitetas. 


\title{
DVIEJŲ SKIRTINGŲ SVORIO METIMO BŪDŲ (GREITO IR VIDUTINIO GREITUMO) POVEIKIS PROFESIONALIŲ IMTYNININKŲ KŪNO MASĖS KOMPONENTŲ IR JËGOS KAITAI
}

\author{
Birutė Matulevičiūtē ${ }^{1}$, Renata Žumbakytė-Šermukšnienè ${ }^{1,2}$, \\ Pranas Mockus², Agnẻ Bieliūnaitè ${ }^{1}$ \\ Lietuvos sveikatos mokslu universitetas, Medicinos akademija ${ }^{1}$, Kaunas, Lietuva \\ Lietuvos sporto universitetas ${ }^{2}$, Kaunas, Lietuva
}

\begin{abstract}
SANTRAUKA
Tyrimo pagrindimas ir hipotezè. Dažnai imtynininkai nori per labai trumpą laiką mažinti kūno svorị iki jiems reikiamo. Literatūroje rašoma: reguliuojant kūno masę svarbu, kad nekistų kūno kompozicija. Norèta patikrinti, ar mažinant kūno masę greitai ir vidutiniškai greitai kinta imtynininkų raumenų jèga.

Tikslas - nustatyti skirtingų kūno masès mažinimo būdų (greito, vidutinio greitumo) poveikį imtynininkų masės komponentų bei jègos kaitai.

Metodai. Tiriamujų grupès: pirma - nemažinę kūno masès imtynininkai $(\mathrm{n}=47)$, antra - imtynininkai, mažinę kūno masę greituoju būdu $(\mathrm{n}=16)$, trečia - imtynininkai, mažinę kūno masę vidutinio greitumo būdu $(n=9)$. Raumenų jèga (dinamometru MMT) ir masès komponentai (bioimpedanso metodu, Tanita 300) ivvertinti prieš kūno masès mažinimą ir po jo.

Rezultatai. Prieš kūno masès mažinimą (greitai ir vidutiniškai greitai) imtyninkų kūno masẻ buvo didesnė $(\mathrm{p}<0,05)$ nei sumažinus kūno masę. Imtynininkai prarado 4,5\% kūno masès mesdami ją greitai $(24-72 \mathrm{~h})$, o vidutiniškai greitai (nuo 72 h iki 2 savaičiu) - 4,03\%. Po kūno masès mažinimo imtynininkų liesoji kūno masẻ grupèse turèjo tendenciją mažèti. Imtynininkų, mažinusių kūno masę greitai, abiejų kojų jèga sumažèjo $(p<0,05)$, o mažinusių vidutiniu greičiu - sumažèjo kairès kojos jèga $(\mathrm{p}<0,05)$. Tirtų imtynininkų po kūno masès mažinimo (greitai ir vidutiniškai gtreitai) kairès ir dešinès rankų jèga sumažèjo $(\mathrm{p}<0,05)$.

Aptarimas ir išvados. Tiriamieji naudojo agresyvų kūno masès mažinimo būdą. Juos būtina mokyti, kaip tinkamai maitintis ir optimaliai sumažinti kūno masę. Tendencingas liesos kūno masès mažèjimas rodo raumenų jègos mažèjimą.

Imtynininkų, mažinusių kūno masę greitu ir vidutinio greitumo kūno masès mažinimo būdu, kojų ir rankų raumenu jẻga reikšmingai sumažèjo.
\end{abstract}

Raktažodžiai: kūno masès mažėimas, dehidratacija, kūno masès komponentai, dziudo. 